International Review of Social History 43 (I998), pp. 42I-436

(C) 1998 Internationaal Instituut voor Sociale Geschiedenis

\title{
The Nation and Its Deserters: Conscription in Mehmed Ali's Egypt*
}

\author{
Khaled FaHMY
}

\begin{abstract}
"Could a Nation, in any true sense of the word, really be born without war?" Such was the question raised by Michael Howard, the eminent Oxford military historian in a public lecture delivered on the topic of "War

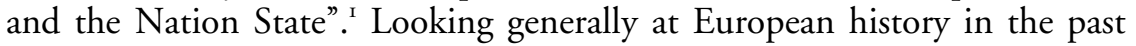
two centuries he argued that war was indeed central for the appearance of the modern nation-state and that modern armies are somehow intimately linked to the rise of nationalism. During the first half of the nineteenth century this argument could very well be applied to Egypt. Having been incorporated in the Ottoman Empire for more than two and a half centuries, Egypt, by the beginning the nineteenth century and mostly through an unprecedented war effort that was concurrent and often synonymous with state-building, had come to play an increasingly independent role on the international plane.
\end{abstract}

Mehmed Ali, who ruled Egypt for the impressively long period of over forty years (1805-I848), is the one who is very often praised for affecting this change. His efforts at revitalizing agriculture, reforming the educational system, transforming the legal establishment and introducing modern industry are often seen as qualifying him to occupy the position of "Founder of Modern Egypt". ${ }^{2}$ However, it is his founding of a modern army that allows him to occupy this unique position in modern Egyptian historiography. Started in the early I820s, this army was central to all his reforms: the different schools, factories and hospitals were all founded to serve it and it was their main raison d'être. Indeed, such was the close inter-connection between the military and other sectors of the state and the economy, that Egypt, by the late I820s and for all practical considerations, had become a military state. Armed to its teeth, Egypt midway in Mehmed Ali's long

* This paper was first delivered in a panel on "Conscription and resistance in the Middle East", which was part of a larger conference on "Languages and Cultures of the Middle East, 19471997", which was held at the Catholic University of Nijmegen, The Netherlands, I-4 October, 1997. I wish to acknowledge the assistance given to me by organizers of the Conference, namely the International Institute of Social History and the Catholic University of Nijmegen and also the participants in my particular panel for the valuable comments I received on it.

I. Michael Howard, War and the Nation State (Oxford, 1978), p. 9. On the connections between armies and the formation of modern nation-states, see Charles Tilly, Coercion, Capital and European States, AD 990-1990 (Cambridge, MA, 1990), and Anthony Giddens, The Nation-State and Violence (Berkeley and Los Angeles, 1985).

2. Henry Herbert Dodwell, The Founder of Modern Egypt: A Study of Muhammed Ali (Cambridge, I93I). 
career managed to expand its borders and to incorporate such neighboring areas that included the Sudan, Syria, Western Arabia, Yemen, Crete, and large parts of southern Anatolia, an achievement that nationalist historians typically bask in.

Above all, though, it is the fact that this was a conscript army that makes this institution occupy a prominent position in Egyptian nationalist historiography. It is often argued that by conscripting the Egyptian peasantry and by giving them the chance to bear arms and to defend their fatherland for the first time in centuries and even in millennia this army allowed the soldiers to discover their true identity, i.e. that they were essentially and truly Egyptians and that their identities as Muslims or as Ottoman subjects were either artificial or secondary. One modern nationalist historian put it thus: "[The peasants] who for centuries had been tied down to the land and cheated of their liberties, were at last to be resurrected from oblivion and to be taught for the first time since Saladin the fundamental lessons of citizenship and nationalism." ${ }^{3}$ The problem with this argument is that the population of Egypt, as will be shown below, far from enthusiastically flocking to serve in the army, was in fact very resentful of military service and strongly resisted joining the colors. Recognizing that the scale of this resistance was alarming, it is still common to argue that this was only a temporary reaction caused above all by "the fellah's strong attachment to his land and the unfamiliarity of military life to him". ${ }^{4}$ The opposition to the service in the "national" institution is explained away by insisting that this opposition was caused by the "fellahin's" strong attachment to the land, a sentiment that proves their "nationalist" feelings. Once the "fellahin" came to realize the benefits of military life and that serving in the army is the most truthful way of defending the land they loved so much, they ceased to resist it and ultimately even became proud of belonging to it. ${ }^{5}$ The rural population of Egypt was, accordingly, taught that serving in the army, while requiring them to abandon their much beloved land, was in fact the best way to express their loyalty to it and to defend it with their lives if need be, and the Pasha's army was seen as the "school" in which they were "taught" how to identify themselves as "Egyptians". This identity now appeared as natural and more essential than any local or religious identity they might have adopted. Being a Muslim or an Ottoman subject was suddenly seen as either "artificial" or secondary compared to this "primordial" identity. In that sense the army that Mehmed Ali founded is seen as "the prime pillar of Egyptian independence". ${ }^{6}$

3. M.A. Rifat, The Awakening of Modern Egypt (London, 1947), p. 38.

4. Jamil 'Ubaid, Qissat Ihtilal Muhammad 'Ali lil-Yunan [The Story of Mehmed Ali's Occupation of Greece] (Cairo, 1990), pp. 79-80; Ahmad 'Izzat 'Abdel-Karim, Tarikh al-Ta'lim fi 'Asr Muhammad 'Ali [History of Education in Mehmed Ali's Reign] (Cairo, 1938), pp. 36-37.

5. 'Abdel-Rahman al-Rafi, 'Asr Muhammad 'Ali [Mehmet Ali's Reign] (Cairo, I95I), p. 33I.

6. Ibid., p. 32I. 
This paper takes issue with this powerful, monolithic discourse of Egyptian nationalism. It questions the validity of the claim that this army played a significant role in awakening the Egyptian peasants from their long slumber and in enlightening them as to their true, but hidden, identities. By reviewing the origins of the idea of conscripting the Egyptian peasantry, the initial steps taken to raise men from the countryside, and the reaction that this unprecedented move triggered with the rural population it is hoped that a truer assessment of the nature of this army can be gleaned. The paper concentrates on the reaction of the peasants to what is supposed to be the national institution, and argues that acts of resistance of the peasantconscripts show not their true and umbilical attachment to their lands, but their aversion to Mehmed Ali's policies and to his officers' elitist practices towards them.

\section{THE ETHNIC COMPOSITION OF THE ARMY}

Before looking closely at the manner in which the men were conscripted, though, it is important to elaborate on an important feature of this army, namely the ethnic division between the officers and the men. For when he first conceived of founding a conscript army, Mehmed Ali certainly had no intention of allowing Arabic-speaking Egyptians to assume senior positions in the army. Rather, his plan was to appoint his personal slaves (mamluks) to high positions, and his Turkish-speaking officers to lower ranks, while the Egyptian conscripts would make up the soldiery. ${ }^{7}$ Eventually, mamluks and "Turks" fused together into one group and it became difficult to differentiate between them. The main distinction, however, was between soldiers and officers: soldiers were Arabic-speaking, while officers spoke Turkish. For the Pasha clearly had in mind the idea of creating a conscript army in which the soldiers would be firmly dominated by their officers. He once told a distinguished French visitor, "I have not done in Egypt except what the British are doing in India; they have an army composed of Indians and ruled by British officers, and I have an army composed of Arabs ruled by Turkish officers [...] The Turk makes a better officer, since he knows that he is entitled to rule, while the Arab feels that the Turk is better than him in that respect." ${ }^{\text {" }}$

As a rule Arabic-speaking Egyptians, referred to as evlad-ı Arab (literally, sons of Arabs), were not allowed to be promoted beyond the rank of captain and very few of them were even promoted to that rank in the first place. As to the ranks of lieutenant and second lieutenant half of them had to be

7. Dar al-Watha'iq al-Qawmiyya, the Egyptian National Archives (hereafter DWQ): $S / \mathrm{I} / 48 / \mathrm{I} / 3$ on I3 Shawwal I238/23 June I823.

8. Georges Douin (ed.), La mission du Baron de Boislecomte, L'Égypte et la Syrie en I833 (Cairo, I927), pp. IIO-III. 
"Turks" and the other half "Arabs". Before signing the orders promoting men to these ranks, Ibrahim Pasha, Mehmed Ali's son and commander-inchief of his forces, had to enquire if the nominees were from "those who can be promoted to these ranks, since it is against the rules to have more than four Arab lieutenants per battalion". Nominations for promotions to upper ranks, on the other hand, usually stated the place of birth of the candidate, to make it clear that he was a "Turk".

Being a Turk, that is speaking Turkish and having one's origins in Anatolia, Istanbul, Albania or other parts of the Ottoman world, was therefore enough for a man to be considered a candidate for a senior position in Mehmed Ali's army even if he had originally been caught as a POW!' After defeating the Ottoman army in the various battles in Syria, a considerable number of officers and soldiers were taken prisoner. A number of those who had been taken prisoner were appointed as officers in the Egyptian army, a policy that caused much resentment among the soldiers. They complained, saying, "Why do we sacrifice our lives and put ourselves in danger to capture these men only to find them appointed as our officers ruling above us?" Neither Mehmed Ali nor Ibrahim found any problems with this practice, although Ibrahim, being closer to the soldiers and more sensitive to their sentiments, might have been more apprehensive than his father about it. As far as both men were concerned, these were evlad-ı Türk (literally, sons of Turks) who were more entitled and capable than "Arabs" to be appointed as officers.

These basic and essential differences between officers and soldiers caused considerable tension between the two groups. Some officers were cheating their soldiers, selling them goods at ten times their price on the market "until they were left penniless". The habit of insulting and abusing soldiers was so widespread that Ibrahim had to write and distribute a general pamphlet to all the regiments in Syria reminding the officers that it was due primarily to the "bravery and zeal" of the soldiers that the army was victorious in its numorous battles. He ordered them not to abuse or insult their soldiers and to send them to a court martial (divan) to be tried there according to the law, rather than take the law in their own hands. He warned the officers that whoever was found violating these orders would be expelled from service altogether. ${ }^{\text {II }}$

In spite of this clear and stern warning, however, it proved difficult to force the officers to treat the soldiers respectfully and complaints about such bad treatment would not stop. Even if one argues that Ibrahim was more sensitive than his father concerning the sentiments of his "Arab" soldiers,

9. For the same prerequisites for joining the civil service, see Hilmi A. Shalabi, al-Muwazzaffun fi Misr fi 'Asr Muhammad 'Ali [Public Employees in Egypt During the Reign of Mehmed Ali] (Cairo, 1989), pp. 29, 63.

IO. DWQ: Sham II/IO5, on I2 Rabi’ II I248/8 September I832.

II. DWQ: Sham I5/I46, on 23 Rajab I248/I7 December I832. 
the problems he had with his officers were deeply ingrained in the army and were much more formidable than could be solved by his ostensibly liberal ideas. ${ }^{\mathrm{I}}$ In other words, when push came to shove Ibrahim knew where his true interests lay: with his father and the mamluk-Turkish elite that formed the core of the officer corps.

If the ethnic composition of this army betrays its dynastic as opposed to its alleged national character, could it be argued that the soldiers, nevertheless, saw the army as a national army, i.e. an army that was fighting for the defence or the glory of the fatherland? Having seen that the ethnic division between them and the officers who commanded them was an in-built feature of the army they served in, can one still present an argument that within that particular institution the soldiers had the opportunity to participate in an experience that would make them think of themsleves as "Egyptians"? Could it be said that the army, although not intended to create such feeling, might have created it unwittingly?

To answer these questions one will have to follow the soldiers closely after they had been conscripted. Conscription and the peasants' reaction to it are the litmus test that can detect the nature of this army and check the allegation that it was in fact a national one.

\section{ORIGINS OF THE IDEA OF A REGULAR, STANDING} ARMY

When Mehmed Ali became governor of Egypt in 1805 at the young age of thirty-five he was aware that he had been given one of the wealthiest Ottoman provinces to rule. However, he was not deceived into thinking that his position was a secure one. For one thing, he came to power as a result of a "revolutionary moment" in Cairo whereby a coalition of local forces had coerced the remote Ottoman government to submit to their demands and to appoint Mehmed Ali against its wishes. As such, the Pasha knew only too well that his appointment to the province of Egypt, while decreed by Istanbul, had in fact been forced on Sultan Selim, and he was wary that he might be deposed at the first opportunity. This wariness continued to haunt Mehmed Ali throughout his long career as governor of that important province of the Ottoman Empire, and Egypt's history in the first half of the nineteenth century was considerably shaped by his attempt to make his tenure there more secure and permanent.

Crucially lacking for him was any reliable military force that would entrench him more firmly in his prized province and which would enable

I2. Ibrahim is quoted by a French military adviser as saying, "I am not a Turk. I came as a mere child to Egypt, and since then the Egyptian sun has changed my blood and made me wholly Arab": Douin, Boislecomte, p. 249. For the differences between father and son regarding how to treat the "Egyptians", see Afaf Lutfi al-Sayyid Marsot, Egypt in the Reign of Muhammad Ali (Cambridge, 1984), p. 97. 
him to confront any probable attempt by the Sultan to dislodge him from it. With this aim in mind he went ahead with characteristic methodical thoroughness, first disposing of the mamluk chieftains in the infamous massacre of the Citadel in I8II, then four years later (in I8I5) with a failed attempt to subdue the rebellious Albanian contingent that had brought him to power ten years earlier, and finally in 1820 with a daring, but disastrous campaign to the Sudan to collect men for his planned army. After four years in the Sudan his Turkish-speaking forces managed to gather 20,000; but only 3,000 remained alive! The others perished "like sheep with the rot". ${ }^{\text {I3 }}$

It was this last attempt that prompted Mehmed Ali to turn finally to the population of Egypt to supply him with the desperately needed manpower for his army. Conscripting the Egyptians was resorted to not because they were believed to make good soldiers, let alone because they were thought to be entitled to serve in their country's army, but because Mehmed Ali could not satisfy his dynastic needs by using any other source of manpower. The fateful decision to conscript the Egyptian peasants was specifically triggered by Mehmed Ali's desire to protect his fellow "Turks": when he realized that the Sudan campaign was turning into a big fiasco and especially when he was informed that a large number of his Turkishspeaking officers were deserting the campaign and were returning en masse to Egypt, he wrote to the governor of one of the southern provinces telling him that "since the Turks are members of our race and since they must be spared the trouble of being sent to remote and dangerous areas, it has become necessary to conscript around 4,000 men from Upper Egypt [to replace them]". These troops, he went on to explain, were to be drafted for a period of three years after which they would be given a stamped certificate and allowed to return to their villages. ${ }^{\mathrm{I}}$ Dated early 1822 , this was the first conscription order issued by the Pasha in Cairo, an order which ushered in a long and burdensome policy that exhausted the Egyptian countryside in an unprecedented manner.

These new conscripts were sent to training camps in Upper Egypt where the nucleus of the officer corps was also being formed out of mamluks belonging to the Pasha and to members of his family, chief among whom was his son Ibrahim Pasha. While the new soldiers were being drilled, the officers were also being trained by a group of French officers who had earlier served in Napoleon's army and who were seeking employment after the demobilization of the Emperor's military forces. Chief among them was a certain officer by the name of Sèves who claimed to have been a colonel in Napoleon's army and to have witnessed Waterloo and whom the French Consul-General in Egypt, Drovetti, had introduced to the Pasha. Sèves

13. Dodwell, The Founder of Modern Egypt, pp. 64-65.

I4. DWQ: S/I/5O/2/I45 on 25 Jumadi I I237/I8 February I822. 
would eventually convert to Islam, assume the Muslim name of Soliman Agha, and rise in the military hierarchy to acquire the title of Pasha and to be second only to Ibrahim Pasha.

The Ottoman model was not far from the Pasha's eyes, however, when he planned his new army. For soon after commanding Sèves to attend to his business, he explicitly ordered Ibrahim Pasha to adopt the structure that Ottoman Sultan Selim III had used in his own army more than twenty years earlier. "Although the plan that Soliman Agha (i.e. Sèves) had put down is a wonderful one," he told Ibrahim, "it is similar to the one that Napoleon had used to lead an army composed of several thousand troops. Our army, however, is a new and much smaller one and we have only recently begun to create it." ${ }^{\text {Is }}$

Both Mehmed Ali and Ibrahim had practical minds and they found no problem in adopting the Ottoman model to fit their new army while at the same time borrowing from the French the idea of conscripting and arming the peasants. Unlike the French army, however, Mehmed Ali's new army, as was said above, was to be ethnically divided. This ethnic division was aimed at two things. First, it was intended as a means to attract men from all over the Ottoman world to come and serve Mehmed Ali and his expanding household. Through these positions and others in the civilian bureaucracy, which was also rapidly expanding, a loyal elite was being cemented around the Pasha and his family. Second, it was also aimed at denying the Arabicspeaking masses the possibility of challenging the Pasha's rule if they assumed leadership roles.

The need to keep the peasants, by far the overwhelming majority of the Arabic-speaking masses, in this inferior and submissive position was felt to be especially crucial, for in addition to the potential danger to agricultural production that moving these thousands of men would cause, conscripting the peasantry was an unprecedented move whose danger lay in giving them arms precisely at a time when resentment to the government's harsh policies was already high. By the 1820 s the Pasha had instituted a wide-ranging monopolies program and had it extended to include most of the major staple foodstuffs and many other cash crops. In addition, and in order to undertake his numerous and often ambitious public works program the Pasha had a much wider recourse to corvée than any other similar program previously seen in Egypt. As if this were not enough, and to finance his various projects, the Pasha had increased land tax to the degree that it could safely be said that by the I82os the countryside had reached its maximum limit to meet the Pasha's insatiable needs. ${ }^{16}$

As a result of this deeply felt resentment to the Pasha and his already detest-

I5. DWQ: S/I/50/2/209 on I8 Rajab I237/Ir April I822.

16. Kenneth M. Cuno, The Pasha's Peasants: Land, Society, and Economy in Lower Egypt, I7401858 (Cambridge, 1992), p. II7. 
able policies the countryside could not withstand yet more pressure put on it. The decision to conscript the fellahin had serious repercussions that posed an alarming threat to Mehmed Ali's authority. Immediately after introducing conscription in Lower Egypt in I823 a big revolt erupted in Minufiyya province and the Pasha had to go there in person guarded by his own palace troops and assisted by six field cannons to subdue the revolt. The following year an even larger rebellion broke out in Upper Egypt that was soon joined by more than 30,000 men and women. Looting, arson and attacks on local officials were reported to the Pasha in Cairo who decided to deal with the rebellion by sending his newly formed troops to quell the revolt.

This was a serious gamble, indeed, for the troops were sent to the very same provinces from which they themselves had been conscripted. This risky move paid off, though, when one of these new regiments marched on to the centre of the revolt in Qina, and managed to quell the revolt in two weeks, leaving 4,000 casualties. The new troops had two other chances to prove themselves to the Pasha. A contingent of 2,500 troops that had been sent to the Hijaz to deal with renewed fighting in Arabia managed to inflict a decisive defeat on a force of Wahhabi warriors ten times its size. A short while later, on 24 March I824, a huge explosion took place in a powder magazine inside the Citadel in Cairo and more than 4,000 people were killed. There were rumours that the explosion was the work of the old Albanian troops who had been hard hit by the Pasha's creation of his new disciplined troops. This posed a grave danger to the Pasha whose position was compared to that of Sultan Selim when he unsuccessfully attempted to get rid of his old guard Janissary troops seventeen years earlier. A single battalion of the new troops, however, rushed to the scene, isolated the powder magazine, and quickly brought the situation under control.

These repeated tests that the new troops passed completely hypnotized Mehmed Ali and he set his bureaucratic machinery going to conscript more and more peasants into his new army. Starting with the figure of a mere 4,000 men the number of conscripts was eventually to reach the impressive figure of 130,000 troops less than ten years later. While the significance of this army does not solely lie in its size, ${ }^{17}$ understanding the manner in which this large number of men was conscripted is central for knowing the nature of the government machinery behind it, as well as its impact on the rural population of Egypt.

\section{CONSCRIPTION METHODS}

As was said above, the first attempt at conscripting the Egyptian fellahin stemmed from the desire to relieve the Turkish soldiers in Mehmed Ali's

17. For a fuller analysis of the impact of the army on Egyptian society, see Khaled Fahmy, All the Pasha's Men: Mehmed Ali, His Army and the Making of Modern Egypt (Cambridge, 1997). 
pay from serving in the remote and hot lands of the Sudan. The 4,000 peasants that were gathered from villages in Upper Egypt to replace them were to be conscripted for only three years at the end of which they would each be given a stamped certificate and allowed to return to their villages and resume their normal, civilian lives. These early conscripts were to be collected not by the village shaykh, but by a conscripting officer sent from Cairo for that purpose. The shaykh was only to assist him in finding men in his village who were suitable for military service. ${ }^{18}$

In issuing the conscripting officers their orders Mehmed Ali tried to impress upon them that they had to handle this important task delicately. He wrote to Ibrahim Pasha telling him that he had been informed that the conscripting officers were gathering men from the villages in the same manner as collecting men for corvée. He told him that this method had to be stopped at once.

Since the fellahin are not used to military service, [he explained], they should not be dragged into the army by force. We have to attract their minds to it [ . . ]

This can be done by employing some preachers who should convince the fellahin that [serving in the army] is not like corvée. [ . . . Alternatively, we can remind them of how easy it was for the French [while they were in Egypt] to collect Copts to serve in their army due to their eagerness to serve their faith. If that was the case with the Copts, it will certainly be more so with the fellahin whose hearts have been enflamed by their religiosity and their zeal in defending Islam. ${ }^{19}$

This was wishful thinking on the part of the Pasha. In fulfilling their duties, the conscripting officers encountered problems that were much more serious than could be solved by simply appointing preachers to attract the minds of the fellahin to military service. In addition to lacking any detailed information about the population, the authorities also did not as yet have a reliable medical system to screen the conscripted. Moreover, unlike the recruiting officers of the French Revolutionary and Napoleonic armies, ${ }^{20}$ for example, the officers sent from Cairo to conscript the fellahin had no guidelines with regards to the age, marital status or number of brothers of the men they should conscript. Lacking this vital information, the conscripting officers, on receiving their orders, would descend upon any given village and seize as many men as could be found "without any order, arrangement, inscription, or lot-drawing". ${ }^{21}$ These men would then be tied together with ropes around their necks in groups of six or eight. ${ }^{22}$ They would then be

I8. DWQ: S/I/50/2/I45 on 25 Jumadi I I237/I8 February I822.

I9. DWQ: $S / \mathrm{I} / 50 / 2 / 186$ on 6 Rajab I237/29 March I822.

20. Isser Woloch, "Napoleonic Conscription: State Power and Civil Society", Past and Present, III (1986), pp. I02-IO5; and Alan Forrest, Conscripts and Deserters: The Army and French Society During the Revolution and Empire (Oxford, 1989), p. 27.

21. Sir John Bowring, "Report on Egypt and Candia", Parliamentary Papers, Reports from Commissioners, 2I (I840), p. 52.

22. Jules Planat, Histoire de la régénération de l'Égypte (Paris, I830), pp. 76-77. 
marched off to the training camps escorted by the "conscription gang", leaving behind a "heart-stricken, sorrowful group" of wives, mothers and children wailing and screaming and hopelessly trying to prevent the soldiers from taking away their men. ${ }^{23}$

All attempts to persuade the fellahin that serving in the army was a religious duty and that being drafted was not like corvée labor fell on completely deaf ears. Even before the Pasha had turned against the Ottoman Sultan, the call to arms in defence of the faith, either against the Greek "rebels" or the Wahhabis of Arabia who were seen as "heretics", was a completely alien and meaningless call with little or no emotional appeal. "A recruiting party with all the allurements of drums, ribbons, and promises, might march from Rosetta to Assouan without picking up a single volunteer [...]" ${ }^{\prime 24}$ Anxious about the lot of their families left behind and the land that would necessarily lie fallow the peasants gradually found little incentive to join the colors, and given the illogical, most arbitrary and unsparing method of conscription, they attempted to resist it through all means possible.

\section{REACTION TO CONSCRIPTION}

It is here that we come to the nub of the problem facing Mehmed Ali and his military authorities: the Pasha never succeeded in inducing the fellahin to join the colors of their free will by employing ideological or religious arguments. Soon after the new conscription policy had become known in the countryside the fellahin employed different methods to escape the Pasha's conscription gangs. One such method was open rebellion, and mention has already been made of the two known rebellions that broke out in I823-I824 as a result of introducing conscription on a large scale. Besides open revolt the fellahin often deserted their villages altogether to avoid being taken into the army. As soon as news of the approach of the recruiting party reached a village, "and it spread over the country like wildfire", ${ }^{25}$ a wave of desertion followed with masses of families fleeing their homes and villages desperately trying to evade the conscription gangs. By the late I8zos this practice was so widespread that entire villages were found completely abandoned, leaving behind sad, deplorable villages "buried in their stillness, [. . . ] where the dwellings of the poor inhabitants [...] still standing, neither blackened by fire, nor destroyed by war, nor decayed by time, but deprived of their inhabitants [who attempted to avoid the agents of the Pasha] by giving up house and home, and deserting, en masse, the devoted town or village". ${ }^{26}$

23. James Augustus St John, Egypt and Mohammed-Ali (London, 1834), vol. II, p. 277. See also P.N. Hamont, L'Égypte sous Méhémet-Ali (Paris, I843), vol. II, p. I2.

24. C. Rochfort Scott, Rambles in Egypt and Candia (London, I837), vol. II, p. 219.

25. St John, Egypt and Mohammed-Ali, vol. I, p. I89.

26. Richard R. Madden, Egypt and Mohammed Ali (London, I84I), pp. 4I-42. 
When the fellahin saw that open revolt and group desertion were ineffectual in evading the conscription gangs of the Pasha they resorted to more tragic acts of rebellion. One such method was to maim themselves deliberately so as to be declared medically unfit for service. Initially, the most common way of maiming was to remove the front teeth to be deemed incapable of loading the muskets. However, when Mehmed Ali was informed that a lot of men in Upper Egypt had resorted to this habit, he said that since the training manuals did not specify which teeth should be used in loading the musket, these men could still use other teeth and should therefore be conscripted. ${ }^{27}$ Other ways of maiming were more dangerous and resulted in serious bodily harm. One such method resorted to by the fellahin was to blind themselves (or at least cause serious inflamation in their eyes) by putting rat poison in their eyes. On hearing about this terrible practice, Mehmed Ali wrote to his provincial governors forbidding the spice merchants from selling rat poison altogether. As for those unfortunates who had actually used it, they were sentenced to life imprisonment in the infamous prison of Alexandria, the liman of Abu Qir. ${ }^{28}$ In one case a woman gouged out the eyes of two men, one a soldier who had deserted from the army, and the other her son (who might have been asked to join the army himself). On being informed about this case, the Pasha ordered her to be drowned in the Nile, the deserter was sent to the liman of Abu Qir, and her son was pardoned. ${ }^{29}$ When the extent of these practices became "very common"30 the Pasha resolved to punish the mutilated men and their accomplices severely by sending them to prison for life, as well as conscripting their relatives instead of them ${ }^{31}$ and to prevent those who assisted the men in maiming themselves, usually their wives or mothers, an order was issued to hang these women at the entrances of their villages so "as to be an example to others". ${ }^{32}$ When the maimed were of no practical use to the army, they were consistently sent to the liman of Alexandria for life..$^{33}$ Otherwise if it were judged that they would be useful in other government

27. DWQ: S/I/48/4/648 on I8 Jumadi II I250/23 October 1834.

28. Amin Sami, Taqwim al-Nil [Chronicle of the Nile] (Cairo, 1928), vol. II, p. 362, Letter dated I7 Sha'ban I245/II January I830. The liman of Alexandria, originally built in 1829 as the Arsenal Works, eventually became a large prison reserved for serious "criminals" from all over Egypt and incarcerating them usually for life.

29. Ibid., p. 365, Letter dated I3 Dhu al-Qi'da I245/6 May i830. See also the case of the mother who chopped off the finger of her son who had been released from one of the Pasha's schools but was asked to be taken there again. She was whipped 200 lashes: S/6/2/I/5 p. 52, on 7 Shawwal I264/6 September 1848 .

30. Bowring, "Report on Egypt", p. 52.

31. St John, Egypt and Mohammed-Ali, I, pp. I89-191. See also Scott, Rambles in Egypt, II, pp. 217-2I8.

32. DWQ: $S / \mathrm{I} / 48 / 3 / 235$ on 7 Rajab I243/25 January 1828 .

33. DWQ: S/I/48/4/365 on I4 Shawwal I249/23 February I834; Awamir lil-Jihadiyya I/I59, on II Ramadan I253/IO December 1837. 
establishments, then they would be sent there. For example, when workers were demanded for a new powder-magazine, Mehmed Ali ordered 120 of those who had maimed themselves, either by gouging out an eye or by chopping off a finger, to be sent to work in his new establishment. ${ }^{34}$

A clear message was being delivered to the Pasha and his military authorities: the peasants resented his army and were going to extreme lengths to resist serving in it. In response, the Pasha was sending back an equally clear message to anyone who might be thinking of mutilating himself to evade conscription: he would still be taken for the service, if not for the army, then for any of the Pasha's projects. In short, it proved extremely difficult to evade conscription for it seems that there was a stubborn determination on the part of the Pasha that the mutilated would not be spared. When all methods failed in preventing the peasants from stopping this terrible practice, the authorities went ahead with drafting the maimed all the same. On visiting Asyut in I834 a British traveler described a scene where "there was a whole regiment which had been composed of mutilated conscripts, every one of whom had either lost an eye, a finger, or the front teeth" ${ }^{35}$

\section{DESERTION}

As alarming as these cases are, they still do not reveal the degree of aversion that the peasants felt towards Mehmed Ali's army, an aversion that could best be seen when the scale, nature and frequency of desertion is studied closely. For the soldiers fighting in Mehmed Ali's army deserted when they were given the slightest opportunity. They fled from the camps and during marches. They escaped from military hospitals, from military ships, from military schools and from military establishments. Not only soldiers, but NCOs also fled. More significantly the guards themselves fled and the elite regiments, the Guardia Regiments, that were created to catch deserters, among other things, were rampant with desertion themselves.

Desertion was not a matter of individual isolated cases that the authorities succeeded in limiting and controlling; it was a phenomenon that continued to irk the authorities due to its frequency and magnitude as attested to by the fact that the regiments' scribes were given pre-printed tables with "nok$s a n$ ", i.e. missing, being one of their standard headings. ${ }^{36}$ Seeing these reports, both Mehmed Ali and his son were alarmed at the scale of the problem. Ibrahim rejected the officers' claim that it was the increased duties of the soldiers that prompted them to desert. He said that this was a mere pretext and that desertion was due more to the laxity and carelessness of

34. DWQ: Awamir lil-Jihadiyya I/I50, on 5 Ramadan I253/4 December 1837.

35. St John, Egypt and Mohammed-Ali, II, p. I75; see also Bowring, "Report on Egypt", p. 52.

36. See, for example, DWQ: Sham Io/I29, on I6 Rabi’ I I248/I3 August I832. In this case I28 men out of a battalion of 521 were "missing". 
the officers. ${ }^{37}$ His father was of a similar opinion. He wrote to the Director of his War Department telling him that he had seen reports of the various regiments and there was not a single regiment that was not devoid of desertion. The only exception, he added, was the Eighteenth Infantry Regiment, which he took to be proof that desertion could be prevented. He therefore suggested that the colonels of the other regiments be court-martialled. ${ }^{38}$

Having succeeded in escaping from their units, where did these men go? One obvious place was to go back to their villages. After checking the registers and identifying the villages of these deserters, however, an order would be issued to the governor of the province in which these villages lay. ${ }^{39}$ The order would give the names and descriptions of the deserters and on finding them, the head of the village (shaykh al-balad) would be fined fifty piasters for every deserter found in his village as well as receiving Ioo stripes of the whip. ${ }^{40}$ Spies (bassassin) were also sent roaming the countryside searching for deserters. ${ }^{4 \mathrm{I}}$ Otherwise, deserters left for Cairo in the hope that they would not be found there since it was supposedly more difficult to spot strangers in the city. ${ }^{42}$ To curb this, the Director of the War Department would write orders to quarter and street shaykhs to keep an eye open for all deserters who might have sought refuge there. ${ }^{43}$ This was also one of the important functions of the Cairo Police (Zabtiyyat Misr). ${ }^{44}$

Finding it difficult to go back to their villages or to disappear in the anonymity of Cairo, some soldiers attempted to leave Egypt altogether, although even that proved difficult since the bedouins were always on the look-out for any soldiers who succeeded in escaping from their military units. ${ }^{45}$ In spite of this strict surveillance, however, some soldiers managed to escape to the Hijaz and the Pasha had to write to his nephew, Ahmed Pasha Yeghen, who was military governor there, to catch all deserters who sought refuge there. ${ }^{46}$ When it was discovered that some soldiers were posing as pilgrims to escape to Arabia, ${ }^{47}$ all pilgrims were ordered to have a stamped certificate stating their names, the names of their villages and their physical descriptions.$^{48}$ Finally, when one of the Egyptian officials who had

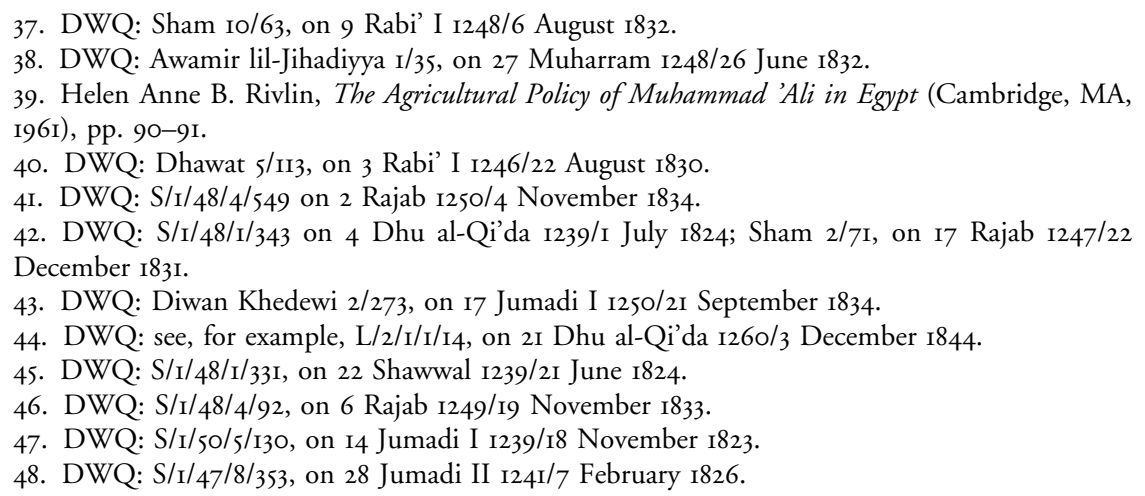


been sent to France told the Pasha that he found a number of deserters in Paris (!), Mehmed Ali in desperation and frustration admitted that desertion was impossible to stop, but that did not mean that nothing could be done about it and he urged senior officers to have a discussion about ways of limiting desertion from their regiments. ${ }^{49}$

Besides ordering the shaykhs to capture any deserters who might have taken refuge in their villages, and threatening them that they would be whipped if they did not comply,,$^{50}$ Mehmed Ali also threatened his own officers "for any negligence that [they] showed in that respect". He said that any officer from whose unit a deserter fled had to find a replacement himself. Otherwise, if he failed, a percentage of his salary would be deducted. ${ }^{\text {st }}$ Furthermore, it was decreed that deserters who had decided voluntarily to return to their units would be pardoned; otherwise on being caught they would each receive 500 stripes of the whip..$^{52}$ In another desperate attempt to control desertion people who caught deserters were rewarded with fifty piastres for each soldier they caught. ${ }^{53}$ Yet the Pasha knew quite well that responsibility for catching deserters ultimately rested with the local and provincial officials whom he warned that if they were not strict in that respect, he would forget their previous services and would beat them up himself. ${ }^{54}$

In spite of all these orders and decrees, in spite of the heavy surveillance that they were under, and in spite of the drastic punishments inflicted upon those who were caught, the peasants were deserting in a steady stream and nothing that the authorities did was effective enough in stopping them from doing so. During the early years of the Syrian campaign (i.e. I83I-1833) it was difficult to know exactly how many men went missing from their units at any one time; the roll-calls gave estimates as low as io per cent and as high as 25 per cent of the size of any one regiment. 55 Fifteen years after the introduction of conscription, however, Mehmed Ali received a report which was most alarming regarding deserters. It said that as many as 60,000 men

49. DWQ: Dhawat 5/208, on 27 Muharram I25I/26 May I835. Neither the nature nor the purpose of the official's visit are stated. His name was given as Mehmed Emin Efendi.

50. DWQ: S/I/47/I4/442, on 2 Sha'ban $1244 / 7$ February I829.

5I. That was for officers from colonel to captain; for those officers from the rank of captain to that of corporal they would be beaten: DWQ: Awamir lil-Jihadiyya I/36, on 28 Muharram I248/ 27 June I832. For an Arabic translation, see Sami, Taqwim al-Nil, II, pp. 397-398.

52. DWQ: Sham II/I7I, on I8 Rabi' II I248/I4 September I832. Four deserters who were caught were punished in that way: Sham II/2IO, on 2I Rabi' II, I248/I7 September I832.

53. DWQ: Sham 2/7I, on I5 Rajab I247/20 December I83I.

54. DWQ: S/I/47/8/35I on 26 Jumadi II I24I/6 February I826.

55. This is based on information from the yevmiyyet, i.e. journals of the regiments. See, for example, that of the 13 th Infantry Regiment in which more than 25 per cent of the soldiers were missing: DWQ: Sham 23/70, on I Muharram I249/21 May I833; and that of the I2th Infantry Regiment in which 13 per cent were missing: Sham Io/69, on 9 Rabi' II I248/6 August I832. 
went missing from the army in addition to 20,000 from the navy $!^{16}$ Bearing in mind that the army could not have been larger than 130,000 , this means that for every three conscripts, one soldier managed to desert.

One of the main reasons behind hating conscription so much was that it was not limited by any fixed period of time in spite of the Pasha's initial order to have it limited to three years. When Ibrahim Pasha realized this after more than ten years of active conscription in which time the countryside had been drained of its male population, he wrote to his father suggesting that they limit the service to a fixed period. He explained:

It is natural for any sane person to resist conscription, since [he views] conscription and captivity as one and the same thing. No conscript would ever have the hope of saying "I will be conscripted for a fixed period, then I will be discharged and live the remaining years of my life [with my family]". Men have the right to think likewise since we do not discharge them except if they receive serious wounds in their hands, legs, eyes or heads; that is, they are discharged only if they are good neither for the army nor [any other] service. This is why we face resistance in conscripting the peasants. ${ }^{57}$

After thinking about it, Mehmed Ali saw the logic of his son's suggestion and wrote back telling him that he decided to limit the period to fifteen years! Ibrahim said that he was going to announce this good news to the soldiers thinking that this showed how merciful and benvolent the Benefactor, as Mehmed Ali was commonly known in Egypt, was. ${ }^{58}$ On second thoughts, however, his father said that this way they would lose a lot of men and suggested that this new system be applied only on the new conscripts and regarding the ones already in service, they would be treated as if they had spent only five years already, i.e. they would be kept for another ten years. ${ }^{59}$

Given this mentality it was natural for the male population of Egypt to hate the army into which they were dragged by Mehmed Ali's war machine and to seize every opportunity to evade it whenever and wherever they could. Nothing can be further from the truth than the common allegation by nationalist historians that the Egyptian peasants eventually saw that the "military life was more comfortable than their village life [which, in fact, is not saying much], and even became proud of it". ${ }^{60}$ In all the numerous cases about conscripting the male population of Egypt into Mehmed Ali's army there was only a single case about a man voluntarily requesting to join the army. He had been released and allowed to go back to his village, then

56. DWQ: Ma’iyya Saniyya, Mulakhkhasat Awamir Mustakhraja min al-Dafatir, Box 3, Booklet

28, Order dated 8 Muharram I253/I4 April I837.

57. DWQ: Sham 30/5IO, on 25 Dhu al-Hijja I250/25 April I835.

58. DWQ: Sham 3I/6, on 7 Muharram I25I/5 May I835.

59. DWQ: Sham 3I/62, on 28 Muharram I25I/27 May I835.

6o. Al-Rafi'i, Asr Muhammad 'Ali, p. 33I. 
some time later came back saying that he had heard from some pilgrims that his village had been deserted and that none of his relatives or friends had remained behind. ${ }^{61}$ This could hardly be viewed as a positive reason for joining the army that Mehmed Ali founded, the "prime pillar of Egyptian independence".

The size and scale is more eloquent than any allegations by nationalist historians regarding how the population of Egypt thought of the Pasha's army and his regime in general. The scale and regularity of desertion was the most striking testimony of the fellahin's willingness to resist a regime they found oppressive, intolerant and inhuman. There was something almost splendid about defying Mehmed Ali and his authorities in that way and at that level. Desertion and the authorities' frustration with it show how much Mehmed Ali's policies had no echo in the peasants' minds and hearts. The Pasha might have created an elaborate machinery to conscript and train the peasants. He managed to aggregate their forces and organize them along European lines and to fight his wars with them successfully. But just as he managed to create what appeared as a disciplined soldiery, the peasants, through desertion, asserted their power to disrupt his machinery and to contest his wish to subjugate them.

By studying the army of Egypt in the first half of the nineteenth century, an army that is supposed to have been the national institution par excellence, this paper found no evidence that this central institution functioned along national lines. As far as the fellah-soldiers were concerned, the allegation that this was their army fighting for their own sake would have been the most ludicrous claim they could have heard. For them, nothing could have been further from the truth. The soldiers came to see the army as the most detestable aspect of the Pasha's already hated regime. They were dragged to serve in it practically for their entire lives, often never to see their families again. During their lifelong period of conscription they were ridiculed, beaten and humiliated by their Turkish-speaking officers. They saw the army as an institution that came to represent to them in the most concrete and direct way the atrocious, inhuman and dreadful policies of Mehmed Ali. Seeing it in this light, they spared no means at their disposal to express their true sentiments of disgust and hatred of the regime that made them pay with their blood and lives for the glory of Mehmed Ali and his family. They might have left us no written records to let us know what their sentiments of the army and the Pasha might have been, but they have made their thoughts known by much more eloquent means: through desertion and maiming they showed that they would use any means to evade an institution that came to represent to them in a very real way all the brutalities of the Pasha's regime.

6I. DWQ: $S / \mathrm{I} / 48 / 4 / 407$, on 3 Dhu al-Qi'da I249/I4 March I834. 